WORKING IN REXDALE: CREATING A LONG-TERM VISION FOR THE REXDALE EMPLOYMENT AREA

\author{
by \\ Sunjay Mathuria \\ Bachelor of Journalism, University of King's College, 2011 \\ A Major Research Paper \\ presented to Ryerson University \\ in partial fulfillment of the requirements for the degree of \\ Master of Planning \\ in \\ Urban Development
}

Toronto, Ontario, Canada, 2016

(C) Sunjay Mathuria, 2016 


\section{Author's Declaration for Electronic Submission of a MRP}

I hereby declare that I am the sole author of this MRP. This is a true copy of the MRP, including any required final revisions.

I authorize Ryerson University to lend this MRP to other institutions or individuals for the purpose of scholarly research.

I further authorize Ryerson University to reproduce this MRP by photocopying or by other means, in total or in part, at the request of other institutions or individuals for the purpose of scholarly research.

I understand that my MRP may be made electronically available to the public. 


\title{
WORKING IN REXDALE: CREATING A LONG-TERM VISION FOR THE REXDALE EMPLOYMENT AREA
}

(C) Sunjay Mathuria, 2016

\author{
Master of Planning \\ in \\ Urban Development \\ Ryerson University
}

\begin{abstract}
While the City of Toronto recognizes the importance of retaining employment lands, it is becoming evident that long-term visions are needed to fully conceptualize the possibilities and realities of these aging, eclectic manufacturing hubs found in the inner suburbs. The purpose of this research is to identify the conditions, constraints and opportunities of the Rexdale Employment Area and develop the groundwork for a Secondary Plan. The first phase of this research project involves conducting a literature review of suburban industry and collecting historical information on Rexdale's employment lands. This is followed by a provincial and municipal policy review for employment lands and how these impact the longevity of the Rexdale Employment Area. A case study analysis of industrial districts in Chicago and Vancouver helps identify possible best practices to implement in Rexdale. Finally, interviews with planners, local employees, industrial associations and community organizations were used to provide perspectives absent from existing literature. A site study of the vacant land at 555 Rexdale Boulevard is used as a way to conceptualize the conditions and opportunities of the Rexdale Employment Area.
\end{abstract}

Key words: employment lands; suburban industry; inner suburbs; Toronto 


\section{ACKNOWLEDGEMENTS}

I would like to first thank my MRP advisor, Dr. Steven Webber of the School of Urban and Regional Planning at Ryerson University. His guidance, encouragement, and sound advice throughout this process are greatly appreciated. It has been a pleasure working with him. I would also like to thank Dr. Chris De Sousa of the School of Urban and Regional Planning at Ryerson University for offering to be my second reader and for his comments and input.

I would also like to thank all those who participated in interviews for this paper. Their input provided the backbone of this paper and the perspectives and passions they shared for Rexdale and employment lands were invaluable and necessary.

Thank you also to my friends and family for their patience over the past two years and for sharing their laughter and support. Finally, many thanks to Georgie and Fredo, for being wonderful feathered and four-legged companions. 


\section{DEDICATION}

For Rexdale, my watan, the longest my family has ever lived in one place.

For my family, who gave me a home in Rexdale. Thank you for sharing your stories.

For my Dad, who taught me how to read the city and to love maps.

For Toronto's countless other under-celebrated suburbs. 


\section{TABLE OF CONTENTS}

\section{Chapter 1}

INTRODUCTION

pg. 1

\section{Chapter 2}

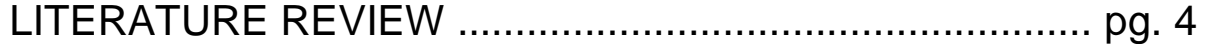

- Urban Deindustrialization ....................................... pg. 4

- Suburban Industry ............................................... pg. 5

\section{Chapter 3}

POLICY CONTEXT \& EMPLOYMENT LANDS ...................pg. 8

- Provincial Policy Statement, 2014 ............................ pg. 8

- Growth Plan for the Greater Golden Horseshoe, 2006 ........................................pg. 9

- Regional Employment Trends ………........................... pg. 10

- City of Toronto's Official Plan ........................................pg. 14

- Official Plan Amendment 231 ......................................pg. 16

\section{Chapter 4}

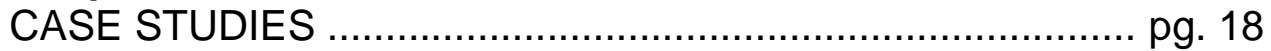

- Chicago: Kinzie Industrial Corridor ...............................pg. 18

- Metro Vancouver: Growth Strategies

for Industrial Lands .pg. 20

\section{Chapter 5}

SITE BACKGROUND pg. 25

- The Creation of Industry in Rexdale ............................pg. 25

- 555 Rexdale Boulevard ............................................. pg. 34

\section{Chapter 6}

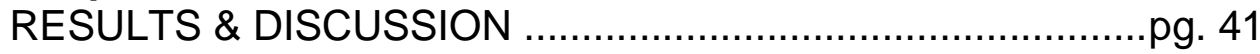

- Planning perspective ........................................................... 41

- Industrial representatives ..............................................pg. 43

- Community organization representative .........................pg. 47

\section{Chapter 7}

RECOMMENDATIONS, NEXT STEPS \& VISION .pg. 50 


\section{LIST OF FIGURES}

Figure 1 Employment District policies in Toronto's Official Plan ..............pg. 15

Figure 2 Multi-level industrial building (conceptual) ..........................pg. 24

Figure 3 City of Toronto's Employment Districts ...........................pg. 29

Figure 4 Distribution of Place of Residence for Employment

in Rexdale Employment District (2006) ...........................pg. 30

Figure 5 Employment Sectors for Rexdale residents ......................pg. 31

Figure 6 Rexdale site map …............................................. 32

Figure 7555 Rexdale Boulevard site map ................................... 36 
Toronto is a city wrapped in the rhythms of work. All night vehicles surge and recede along the urban expressways, as fluid as arteries, their lights pulsating as if propelled by the city's beating heart. At dawn packed buses flounder in the curb land, wallowing like migrating manatees.

(Imagining Toronto, Amy Lavender Harris)

\section{CHAPTER 1: INTRODUCTION}

Blue collar on the bus, just to punch a card

Said you want to battle poverty, get a job

Working 9 to 5, the job is hard

Life is hard, right and left of Rexdale Boulevard,

It's just factory jobs,

That's got most my people sweating everyday...

"Money (Part 1)", Jelleestone

The City of Toronto's history with suburban development complicates our stereotypical images of North American suburbia: white picket fences, gated communities, and an upwardly mobile middle class. Instead, the landscapes of Toronto's inner suburbs are speckled with highrises and industry, and are home to working class immigrant populations. In the northwest corner of Toronto, Rexdale is a largely residential neighbourhood anchored by an industrial and manufacturing hub that was developed in the 1950s. Compared to Toronto's downtown employment lands, Rexdale offered the advantages of more space, the opportunity for a new building, and proximity to major highways and the Malton Airport (now Lester B. Pearson International Airport). However, as the manufacturing sector has experienced general decline over the past 25 years, the vitality of Toronto's many industrial hubs has been called into question. The City's Official Plan Amendment 231 (OPA 231) is an attempt to address the volume of conversion requests received from developers to rezone employment lands to mixed use, residential or commercial uses and strengthen employment 
land policies in response to redevelopment pressures. This research paper investigates the current conditions and opportunities of the Rexdale Employment Area and how the district can be retained and leveraged as an industrial hub for the City. The findings will provide the framework for a Secondary Plan for the Rexdale Employment Area.

The first section of this paper includes a literature review of trends in urban deindustrialization, as well as a contextual analysis of the emergence of suburban industry in North America. This is followed by a section that analyzes provincial and municipal employment policies and how they impact manufacturing areas such as the Rexdale Employment Area.

The third section of this paper involves a case study review of industrial districts in Chicago and Vancouver. Although Chicago has designated Planned Manufacturing Districts (PMDs), the City faces similar pressures as Toronto, with developers siting projects in employment areas close to downtown. Chicago's adoption of a land-use plan for the Fulton District illustrates possible best practices that Toronto can implement in the branding of its own employment areas. Similarly, the examination of Metro Vancouver's Growth Strategy provides possible strategies that can be used to optimize and intensify industrial districts, while maintaining them as key nodes for employment.

The fourth section of this paper provides site background information for the Rexdale Employment Area, which includes historical context and demographics from surrounding residential neighbourhoods. This is followed by a site analysis of the vacant lands at Rexdale Boulevard and Highway 27, which includes 555 
Rexdale Boulevard, the site a proposed casino and entertainment complex beside the Woodbine Racetrack. This section also includes a discussion of the site's contested history and the City's OPA 231 decision to retain the lands for Core Employment uses. An analysis of 555 Rexdale Boulevard provides insight into the employment area's unique challenges and the complications of development in industrial suburban areas.

The fifth section of this paper features an analysis of the Rexdale Employment Area and 555 Rexdale Boulevard, which is informed by discussions with planners, local employees, and representatives from industrial associations and community organizations. The combination of these perspectives have traditionally been absent from existing literature on employment land-use planning and help shape the beginnings of a long-term vision for the Rexdale Employment Area.

The final section of this paper provides recommendations and next steps, which are informed by discussions in the preceding sections. These recommendations identify key issues, strengths and opportunities needed to create a Secondary Plan for the Rexdale Employment Area. In addition, the directives and strategies outlined in this section can possibly be applied to Toronto's other inner suburban manufacturing districts. 


\section{CHAPTER 2: LITERATURE REVIEW}

\section{Urban Deindustrialization}

Industrial manufacturing has historically been the employment heartbeat of many major North American cities. In Toronto, manufacturers and factories punctuated inner city neighbourhoods, following $\mathrm{CN}$ and $\mathrm{CP}$ rail corridors and waterways (i.e., Lake Ontario). The City's manufacturing milieu was diverse and included garment makers, chemical industries, and meat processors as the proximity to downtown Toronto provided manufacturers direct access to a market and a labour force. However, beginning in the 1970s, there has been a gradual deindustrialization of many inner-city neighbourhoods, largely due to economic conditions and the introduction of new technologies -- land became cheaper outside the city, mechanized processes made jobs obsolete, and manufacturers downsized (Catungal, Leslie, \& Hii, 2009). Since the early 2000s, it has not been uncommon to witness aging industrial buildings being converted into lofts, condominiums or mixed-use developments. In particular, industrial lands in desirable locations, in close proximity to downtown cores have become casualties to this phenomenon. The process of deindustrializing Liberty Village is a prime example. Employment uses in Liberty Village have shifted from manufacturing to the "creative class", introducing a new demographic of urban professionals working in creative industries and high-tech firms (Catungal et. al, 2009). Similarly, with the intensification of residential and commercial uses, the city's industrial past has slowly receded from memory. In addition, recent trends in the City's economic development has resulted in a shrinking manufacturing 
workforce and an increase in sectors such as office, research and retail (Malone Givens Parsons Ltd., 2012).

\section{Suburban industry}

As with all North American cities post-World War II, Toronto experienced rapid residential growth outward and became subject to suburban sprawl. Almost half a century of unsustainable growth patterns has resulted in auto-dependence and stale suburban landscapes. In order to prevent further sprawl, especially in suburban municipalities, many North American cities have adopted smart growth policies that encourage density and mixed uses. Some of these smart growth principles include offering a diverse range of housing and fostering the development of walkable and vibrant streetscapes (Duany, Speck, \& Lydon, 2010).

While smart growth policies offer opportunities for developments that create jobs, attract residents and increase local tax revenues, Leigh \& Hoelzel (2012) note that these policies often come in direct conflict with the retention of prime industrial areas. The narrative of urban neighbourhoods is one that has been repeated in many major cities in North America. Industries historically located near waterfronts or rail corridors just outside the city's urban center become attractive sites for developers looking to convert the land for residential and/or commercial uses. The dominant discourse surrounding urban industries is that they are not needed - they are viewed as "unproductive and unattractive". As Leigh \& Hoelzel point out though, this causes contention within planning practice, as more municipalities realize the importance of retaining employment land and an industrial base. 
Recently, [scholars] have attended to the grittier places that were settled by workers and immigrants, including neighbourhoods that grew up beside suburban industry. Even here, however, the factory chimney lies in the background of the picture, offering plausible depth to a scene that is still largely domestic. More commonly still, it has been airbrushed out. (Harris, 2004, p. 221).

The literature on suburban industries, especially those found around Canadian cities is rather scant. The traditional discourse in urban planning has been to typify suburban spaces with certain characteristics: bedroom communities that are bourgeois, mundane utopias. Lewis (2004) notes that the history of manufacturing suburbanization has been overshadowed by discussions of the urban/suburban dichotomy, typically based on race, class, and lifestyle. That is, the suburbs are depicted as white, wealthy, and segregated/exclusive. Conversely, cities are diverse, lower income, and the epicenter of culture. In these works, narratives of the working class industrial suburb are lost.

An overview of the industrial suburbs reveals an early history of "factories, mills, and warehouses [were] clustered on the urban periphery" in suburbs where "few other activities were to be found" (Lewis, 2004, p. 7). Development in the late 1800 s and early 1900 s led many major North American cities to divert investment to city building initiatives in the fringes, rather than in the urban core (Lewis, 2004, p. 8). In addition, rather than relying on railroads and waterways, it became increasingly more affordable and accessible to use trucks to transport goods (Walker \& Lewis, 2004, p. 19). This made it less necessary to be located near urban markets. Finally, manufacturing process shifted from small-scale, specialized producers and more towards mass production and integrated factories, which required larger tracts of land available outside the city (Walker \& 
Lewis, 2004, p. 20). Harris (2004) also distinguishes between industrial "satellites" and "suburbs". Industrial satellites are typically geographically isolated suburban developments centered around a main industry that employs much of the town (such as Gary, Indiana and U.S. Steel) (Harris, 2004, p. 226). The primary reason for industries to develop satellites is to be in close proximity to a labour force. As a result, a mixture of housing and industry would need to be available from the very beginning of the development of industrial satellites (Harris, 2004, p. 227). The development processes of industrial suburbs are more complex and varied. Some fringe suburbs, such as West Toronto Junction, develop around industry, while others were primarily residential at the beginning (Harris, 2004, p. 225). In many other industrial suburbs though, residential and industrial developments alternate, creating a more sustainable and symbiotic relationship. 


\section{CHAPTER 3: POLICY CONTEXT \& EMPLOYMENT LANDS}

\section{Provincial Policy Statement, 2014}

The Provincial Policy Statement (2014) was developed to provide direction on land use planning for municipalities and ultimately affects the every day roles of planners across Ontario. In particular, the Provincial Policy Statement (PPS) is intended to compliment the long-term planning objectives of local policies and integrate "the principles of strong communities, a clean and healthy environment and economic growth" (Ministry of Municipal Affairs and Housing, 2014, p. 1). The PPS directives regarding employment uses are broad, but it noted the importance for planning authorities to retain employment lands for long-term growth (Ministry of Municipal Affairs and Housing, 2014, s. 1.3.2.1). In addition, the PPS cautions planning authorities when processing land conversion requests within employment areas: non-employment uses should be permitted only after a comprehensive review that indicates employment uses would not be required on the land in the long-term (Ministry of Municipal Affairs and Housing, 2014, s. 1.3.2.2). The PPS also offers special protection of employment areas in proximity to "major goods movement facilities and corridors" that are pertinent to the functionalities of employers located in these areas (Ministry of Municipal Affairs and Housing, 2014, s. 1.3.2.3). This protection is especially important, as many suburban industries are located next to major highway interchanges or rail corridors that allow for the movement of goods. With these policies in place, the PPS acknowledges the development pressures that exist in employment areas (i.e., conversion requests) and directs municipalities to understand the importance 
of their employment lands in a proactive manner. The PPS advises planners to consider the interrelated factors (e.g., environmental, economic, social) in landuse planning to guide decision-making for the sustainability of "strong communities, a clean and healthy environment and a strong economy" (Ministry of Municipal Affairs and Housing, 2014, p. 5). The economic viability of Ontario's municipalities, though, is inextricably linked with how existing employment lands are managed and protected.

\section{Growth Plan for the Greater Golden Horseshoe, 2006}

The Growth Plan for the Greater Golden Horseshoe (GGH) provides growth management directives for the geographically diverse hub of the Greater Toronto and Hamilton Area (GTHA). In tandem with existing policies such as the Greenbelt Plan and the PPS, the GGH seeks to tap into the strengths of the GTHA and improve planning initiatives that contribute to "thriving, livable, vibrant and productive urban and rural areas [that] foster community and individual wellbeing" (Ministry of Infrastructure, 2006, p. 9). A key policy directive from the GGH is to "preserve employment areas for future economic opportunities" (Ministry of Infrastructure, 2006, p. 8). The GGH is focused on the region's growth patterns and has identified employment lands as the foundations for the region's continued economic development. In addition to supplying adequate lands for diverse employment uses, the GGH instructs municipalities to preserve manufacturing and warehousing lands that are in the vicinity of "major highway interchanges, ports, rail yards and airports" (Ministry of Infrastructure, 2006, s. 2.2.6.10). This description identifies characteristics of typical suburban industrial districts - 
the Rexdale Employment Area includes a major rail line, borders three major highways and an international airport. Similar to the PPS, the GGH also acknowledges that employment lands can be converted to non-employment uses, but only after a Municipal Comprehensive Review (Ministry of Infrastructure, 2006, s. 2.2.6.5). This Review will investigate the effectiveness of a municipality's Official Plan policies relating to employment lands. Through the Review, the municipality must demonstrate that the conversion is required to support other growth policies and will not infringe upon long-term employment planning or economic development (Ministry of Infrastructure, 2006, s. 2.2.6.5). These GGH policies not only emphasize the importance of retaining employment lands, but ensure they remain integral components of the region's economic growth.

\section{Regional Employment Trends}

In her report "Planning for Prosperity", Blais (2015) examines the implications of employment trends for regional planning in the Greater Golden Horseshoe $(G G H)$. Blais notes that the restructuring of work due to freer trade and globalization has resulted in an intensified competition between regions. A global economy has introduced diverse skillsets that are mobile and innovative ways in organizing the production of goods and services (Blais, 2015). As a result, regions such as the GGH are competing with each other for production facilities and corporate offices. While the manufacturing sector has experienced a decline over the past 10 years (28 percent decline between 2001 and 2014), Blais confirms that certain manufacturing activities are actually experiencing growth. These include steel production, wholesale and distribution, and telecommunication services (Blais, 2015, p. 17). Furthermore, Blais identifies a shift to "high-value- 
added and knowledge-intensive activities" such as digital industries and information and communications technologies (Blais, 2015). Despite this growth in knowledge-oriented sectors, Blais notes that employment lands such the "Airport megazone" (which includes the Rexdale Employment Area) are still important sites for manufacturing activities (Blais, 2015, p. 33). With the second largest concentration of employment in Canada, the Airport megazone contains over 300,000 jobs, which includes 80,000 jobs in manufacturing, construction and utilities. The Airport megazone is crucial to the Greater Toronto Area's employment makeup, occupying large swaths of land and crossing municipal boundaries. However, there is no mention of the Airport megazone in Growth Plan planning objectives or policies, as the Plan tends to be more municipalitybased. In order to enable a more comprehensive plan for GGH growth, Blais suggests it is critical to develop strategies for the Airport megazone, aimed specifically at integrating transit use, identifying opportunities for redevelopment, broadening employment activities and providing amenities for the workers (Blais, 2015). These strategies should be pursued, while retaining the megazone's industrial and manufacturing character and capabilities.

Similarly, the Ontario Growth Secretariat (OGS) recognized the complexity of planning for employment uses in the diverse and varied employment landscapes across the GGH (Ministry of Municipal Affairs and Housing, 2008). In their assessment of the GGH's ever-evolving economic environment, the OGS set directives for the Province to work more closely with municipalities and stakeholders to fully strategize for the region's employment growth. Some of these 
strategies include developing a robust database of existing employment uses across municipalities and setting urban design guidelines to support certain economic activities (Ministry of Municipal Affairs and Housing, 2008). There is also recognition to safeguard industrial employment land, especially in the vicinity of highway interchanges, airports and rail yards (Ministry of Municipal Affairs and Housing, 2008). Stakeholders identified the challenges of incompatible land uses disrupting manufacturing employment lands and cited that industrial-related activities require separation from other, more sensitive land uses. One of the OGS's recommendations to deter this was to undertake a Municipal Comprehensive Review of land use conversion applications that request nonemployment developments in employment areas. This resulted in the City of Toronto's Official Plan Amendment 231, which requires municipalities to reevaluate permitted uses on employment lands. The OGS emphasized the importance of creating a clear land-use framework to guide employment planning that is also flexible enough to respond to changes in economic conditions.

While they recognized the overall decline in manufacturing (in terms of jobs per hectare), the OGS noted that the manufacturing sector is poised to contribute to the GGH's economy in other ways. For example, new technologies provide mechanisms for more efficient production and delivery of goods. A 2015 report by the Centre of Digital Entrepreneurship and Economic Performance (DEEP Centre) examines the future of manufacturing in Ontario and the role of new technologies in the sector (DEEP Centre, 2015, p. 26). DEEP Centre reports that the province's manufacturing sector is being redefined by the growth in robotics, 3D printing, and nanomanufacturing technologies (DEEP Centre, 2015, p. 26). These innovations 
inevitably have land-use impacts and indicate that larger industrial facilities would be needed to accommodate future manufacturing uses.

The growth in the auto sector and food manufacturing could be impacted by the introduction of new, innovative technological processes. For example, 3D printing is an increasingly accessible technology that demonstrates potential for large-scale manufacturing of specific products in food processing, architectural design and health care (DEEP Centre, 2015, pp. 19-20). The DEEP Centre notes that Ontario's relative advantage for 3D printing is existing agricultural production, coupled with a strong food manufacturing sector, which makes 3D printing facilities a "natural compliment in Ontario's factories and laboratories" (DEEP Centre, 2015, p. 20). As such, these technological trends must be considered in employment planning, as they require space and accessibility to existing industries.

Technology-based job growth is contingent on competitive advantages and incentives, as well as access to a specialized, technical labour force. However, new technologies such as robotics and nanotechnology are becoming integral components of existing processes and the need for "nanomanufacturing" is evident (DEEP Centre, 2015, pp. 20-24). The promises of introducing stronger, more durable materials requires products such as nanoscale polymers for automobile bumpers or effective nanosensors in packaged food products to detect contamination to be manufactured (DEEP Centre, 2015, p. 21). These processes can be integrated into existing industries and facilities.

Over the past few decades, the dominant narrative of manufacturing has been 
that it is a sector in decline and is quickly becoming obsolete. However, Blais maintains that this is not the complete story. Manufacturing and warehousing activities still continue on the industrial fringes of the city, but so are other, related work: engineering construction, pharmaceutical production, and telecom services (Blais, 2015, p. 17). Furthermore, the integration of new technological processes must perform symbiotically with these industries. The protection of industrial employment lands, such as the Rexdale Employment Area, are needed to address and provide land-use planning frameworks for ever-evolving employment trends.

\section{City of Toronto}

The City of Toronto's Official Plan (2006) defines Employment Areas as "places of business and economic activity" that supports uses such as offices, manufacturing, warehousing, and distribution" (Section 4-12). Employment Districts are larger employment areas comprised mostly by manufacturing, warehousing, and product assembly activities, which, as specified by the Official Plan, must be protected from non-economic uses (Toronto Official Plan, Section

\subsection{4). The Official Plan outlines policies set out to protect and promote} Employment Districts in order to grow the City's tax base, maintain Toronto's competitive advantage for new businesses, and sustain fulfilling employment opportunities for all Torontonians (Toronto Official Plan, Section 2-20). Specific strategies include permitting a broad range of economic activity in these districts, revitalizing Employment Districts through investments or special partnerships, and supporting business associations (Toronto Official Plan, Sections 2-20, 2-21). Please see Figure 1 for the full list of Employment District policies. 


\section{Policies}

1. Employment Districts shown on Map 2 will be protected and promoted exclusively for economic activity in order to:

a) maintain and grow the City's tax base;

b) attract new and expand existing employment clusters that are key to Toronto's competitive advantage;

c) develop quality Employment Districts that are globally competitive locations for national and international business and offer a wide choice of sites for new business;

d) nurture Toronto's diverse economic base;

e) provide a good overall balance between population and employment growth by creating job opportunities for Toronto residents;

f) provide a range of employment opportunities for Toronto residents that can be reached by means other than the private automobile; and

g) create and sustain well-paid, stable, safe and fulfilling employment opportunities for all Torontonians.

2. Employment Districts will be enhanced to ensure they are attractive and function well, through actions such as:

a) permitting a broad array of economic activity that encourages existing businesses to branch out into new areas of activity and facilitates firms with functional linkages to locate in close proximity to one another;

b) investing in key infrastructure, or facilitating investment through special tools, programs or partnerships, in order to:

i) revitalize Employment Districts which may be experiencing decline because of vacancies and closures, absence of key physical infrastructure, poor accessibility, or poor environmental conditions;

ii) promote the distinctive character or specialized function of a District to attract firms within a particular targeted cluster of economic activity;

iii) facilitate the development of vacant lands; and

iv) create comfortable streets, parks and open spaces for workers and landscaped streetscapes to attract new business ventures; and

c) encouraging and supporting business associations that promote and provide a business voice for the District.

Figure 1: Employment District policies as outlined in the Official Plan.

The land-use planning policies outlined in the PPS, GGH, and Toronto's

Official Plan clearly support the retention and growth of industrial employment

areas. As discussed, these policies underscore the importance of the

manufacturing sector for economic stability and employment opportunities. In 
these discussions, however, there is also recognition of underlying development pressures that impose on employment areas in the City. In response, the City of Toronto initiated Official Plan Amendment 231 in order to address how conversion requests are addressed in employment areas.

\section{Official Plan Amendment 231}

In 2011, the Woodbine Entertainment Group submitted a development proposal that required the conversion of 555 Rexdale Boulevard from Employment - Industrial to Mixed Use, which would permit a portion of the land to be developed for residential purposes (City of Toronto, 2013). This application presented a slight paradox: while it aligned with PPS and Growth Plan policies to promote mixed-use developments and increase residential density, it did not adhere to policies to protect prime employment land.

In their 5 Year Official Plan and Municipal Comprehensive Review, the City of Toronto assessed requests like these to convert employment lands to other uses. This Review resulted in a revision of their employment land policy approach, Official Plan Amendment 231 (OPA 231), which provided a more thorough understanding of the City's Employment Areas. A key update in OPA 231 is identifying distinctions across Employment Areas and understanding the differences between "General Employment Areas" and "Core Employment Areas", the former being small-scale "business and economic activities" that can include retail, service uses and restaurants and the latter being large-scale economic activities that includes manufacturing and warehousing. As a result, Core Employment Areas are typically located within the interior of Employment Areas and permit secondary uses that could support industrial uses, such as 
hotels, parks and small-scale restaurants (City of Toronto, 2013). Conversely, General Employment Areas are located on the peripheries of Employment Areas and permit uses that attract the general public, such as major retailing. This recognition of different uses within Employment Areas (i.e., "core" versus "general") allows for the City to delve deeper into the specific needs and conditions of industrial and manufacturing-specific sites. The working definition for "Core Employment Areas" provides the opportunity to address land-use planning issues within employment districts that receive land conversion requests. When reviewing conversion requests within Employment Areas (General Employment or Core Employment), the City will assess with criteria based on Provincial planning policy and Employment Area policies from the City's Official Plan (City of Toronto Zoning By-Law No. 1714-2013).

In OPA 231, most of the Rexdale Employment Area is listed as "Core Employment Areas". While City staff recognizes the importance of maintaining core employment lands in the area, they do not specify how they envision the site should be developed, or what future development in the Rexdale Employment Area could look like. Furthermore, local residents, business owners and community groups have not been engaged to establish a long-term vision for the site or District itself. 


\section{CHAPTER 4: CASE STUDIES}

This section explores the shifts in industrial employment land-use planning in Chicago and Vancouver. In Chicago, I examine the development and land-use policies of the Planned Manufacturing Districts (PMDs), including the strengths, weaknesses and challenges in the City's attempt to retain urban industrial employment districts. For Canadian context, I discuss Metro Vancouver's Growth Strategy mandate to protect and optimize industrial land development, and any specific challenges and strategies that are identified.

\section{Chicago: Kinzie Industrial Corridor}

By the 1980s, Chicago had experienced what many other North American cities experienced: a decline in manufacturing employment. However, this was particularly felt in Chicago, which had been known as the "city of factories" (Clavel \& Giloth, 2015). As large-scale manufacturing firms began downsizing, Chicago's employment landscape also started to change. In 1983, the Chicago Central Area Committee (CCAC) spearheaded plans to redevelop a downtown working-class industrial neighbourhood into residences for business elites (Clavel \& Giloth, 2015). While these pressures continued, Mayor Harold Washington (elected in 1983) identified the need for the city to retain its industrial jobs and established task forces for various manufacturing sectors, as well as the Local Industrial Retention Initiative (Clavel \& Giloth, 2015). This eventually led to the creation of Planned Manufacturing Districts (PMDs), which provides Chicago's manufacturing sector zoning protections from encroaching non-manufacturing developments (in particular, residential). The rationale was that PMDs would protect Chicago's industrial sectors and established connections for area 
manufacturers (Clavel \& Giloth, 2015). PMDs were created in pre-existing industrial corridors throughout the 1990s and 2000s to safeguard certain areas from gentrification and also attract new businesses to strengthen the City's economy (The University of Wisconsin-Milwaukee, 2005). There was considerable opposition from real estate developers, as many of these lands were deemed particularly lucrative due to the proximity to downtown or waterways (The University of Wisconsin-Milwaukee, 2005, p. 8).

Designated a PMD in 1998, the Kinzie Industrial Corridor includes 1,094 acres of employment lands and was established to "serve the long term needs of existing industries and attract new industrial employers" (Camiros Ltd., Applied Real Estate Analysis, Inc., \& Sonoc/Hutter/Lee Ltd., 1998). The designation also provided for improving public infrastructure in the area, environmental clean-up and preparing sites for industrial development (Camiros Ltd. et. al., 1998). The creation of the Kinzie PMD had the support of residents from surrounding workingclass neighbourhoods because their jobs would remain intact (Fitzgerald \& Leigh, 2002). On the other hand, existing residents in the newly-converted lofts and townhouses opposed the PMD designating, citing it would "turn their neighbourhood into a lonely residential island in an industrial environment" (Fitzgerald \& Leigh, 2002, p. 115). The various subgroups of industrial uses poses some unique challenges for the Kinzie Industrial Corridor. Food processors, recyclers and other intensive uses are primarily located in an area north of Fulton Market that is zoned for both industrial and commercial uses (Fitzgerald \& Leigh, 2002). In 1998, there were a number of vacant and underutilized lands along the Chicago and North Western railroad tracks (Fitzgerald \& Leigh, 2002). The Fulton and Randolph Street Markets are largely light industrial and wholesale food 
districts that also have a number of small manufacturers and other distribution firms.

In 2014, the City adopted a land use plan for the "Fulton Market Innovation District", which would integrate meat packers, food distributors and manufacturers, innovation-driven firms, technology-related jobs, restaurants, retailers and leisure-oriented businesses (City of Chicago, 2014). Although traditionally a manufacturing and food processing area, Fulton Market has expanded its employment uses to include the technology sector: "[the] plan is intended to preserve existing jobs while accommodating private sector investments that reinforce the area's expanding role as an innovation-driven employment center" (City of Chicago, 2014, p. 3). As described in the plan, an innovation district is a type of business center that aims to attract technological or virtual-based companies to act as anchors in existing industrial sectors (City of Chicago, 2014). Within Fulton Market, different subareas are designated for specific types of employment - for example, 'innovation' (or technology-based) companies will be located separately from the food processing and manufacturing-based firms. In addition, non-employment uses, such as restaurants and hotels, are permitted but are limited to certain subareas that would not impede or disrupt the functions of existing industries (City of Chicago, 2014). In essence, this land use plan envisions a section of the Kinzie Industrial Corridor (in this case, Fulton Market) as an important node for employment growth and opportunity. With this plan, the City seeks to leverage Fulton Market's existing strengths as a food processing hub and its proximity to downtown and create a long-term vision for the area to include emerging employment trends. 
This is all accomplished while maintaining Fulton Market's function as a primarily industrial area.

\section{Metro Vancouver: Growth Strategies for Industrial Lands}

Vancouver has traditionally been an important port city and much of its manufacturing and industrial development has centered on the maintenance of international trade links. In 2011, Metro Vancouver (which includes cities such as Delta, Richmond and Surrey) released its Regional Growth Strategy, which provided the mandate to protect the region's existing industrial land base and encourage its intensification capacity (Metro Vancouver, 2012). As the region continues to expand outward from the City of Vancouver, there has been increasing residential and commercial development pressures on employment lands. This has resulted in a growing recognition of land scarcity in the region, which threatens to compromise prime industrial lands. Similar to the City of Toronto, Metro Vancouver realizes maintaining industrial lands will help support an economically sustainable future (Stantec Consulting, 2013).

In order to protect the region's waning supply of industrial lands, Metro Vancouver's Regional Growth Strategy (RGS) emphasizes the need to optimize existing industrial lands and intensify their uses (Stantec Consulting, 2013). In 2010, 25 percent (or 310,000) of Metro Vancouver jobs were located in designated industrial employment areas (Metro Vancouver, 2011). This primarily consisted of manufacturing, transit, warehousing, or wholesaling jobs. With industrial intensification, the RGS seeks to allow sites higher density forms, such as multi-storied and multi-functional industrial facilities. In addition, underutilized 
industrial sites would be subject to redevelopment to facilitate employment growth.

To accommodate growth these strategies, the RGS establishes regional land-use designations, 'Industrial', 'Mixed Employment', and 'General Urban' that specify employment uses within industrial areas (Metro Vancouver, 2011). For example, an 'Industrial' designation would be reserved for industrial activities and appropriate accessory uses limited to office and retail (Metro Vancouver, 2011). 'Mixed Employment' would expand on industrial uses and allow for further office and retail, which must still support the industrial activities. 'Mixed Employment' would be located near urban centres with high-frequency transit available. Finally, 'General Urban' would allow various urban uses, including smaller scale industrial activities. This is similar to OPA 231's distinction between 'General Employment' and 'Core Employment' areas, which permit certain auxiliary uses (e.g., hotels, restaurants, etc.) at the peripheries of employment areas ('General Employment') and maintain manufacturing and industrial uses for 'Core Employment' areas.

To determine the appropriate intensification strategy for a site, Metro Vancouver identified several intensity (amount of activity) and density (amount of building) measures that should be considered. These measures were developed in recognition that a "one size fits all" approach to developing employment lands is not possible and that Metro Vancouver has a diversity of industrial lands and districts, each with their own specific opportunities and constraints. The application of these measures will help determine whether a development is appropriate for a specific site within specific industrial areas. Some intensity measures include vehicular (equipment) movement per hour (trucks, loading, etc.), level of building specialization, transportation infrastructure (rail yards, 
highways, etc.), and number of diversity of businesses per Land Area. Some density measures include Building Floor Area Ratio (building floor space/lot area) and Building Site Coverage (building floor plate/coverage divided by lot area) (Stantec Consulting, 2013, p. 2).

A literature review conducted by Metro Vancouver planning staff found that "productivity increases with increased densities and location economies" (Metro Vancouver, 2011, p. 8). This prompted the exploration of creating flexible building design that accommodates multiple functions while maintaining industrial-based activities. A conventional single-level industrial building has a low floor area ratio and can typically only accommodate one tenant. A two-level building could maintain heavy industrial uses at grade, with light industrial uses on the upper floor. This provides more building space, greater efficiencies, and an increase in business activity and employment (Metro Vancouver, 2011, p. 8). However, both Metro Vancouver's and Stantec's studies discovered potential constraints adverse impacts posed by intensification such as increased traffic compromising industrial function and industrial sites often requiring 50-60 percent of site for vehicular movement and loading (Stantec Consulting, 2013).

Stantec (2013) provided a summary of recommendations to facilitate Metro Vancouver's industrial redevelopment and intensification. While acknowledging financial and market forces playing a role, many of the recommendations and next steps are within the purview of governmental intervention. Summaries of some of the recommendations are outlined below.

1. Transportation and Infrastructure: Transportation services must be planned to support infrastructure development in industrial areas. This will mitigate any 
potential traffic congestion that would affect an industrial business from operating efficiently.

2. Flexible Zoning: Policies should be updated to allow individual businesses to capitalize on the potential for innovation and co-related business functions. Current zoning restrictions impede industries with the ability to add associated office, research, or lab uses within their facilities.

3. Design Guidelines: Specialized design guidelines for industrial areas should be developed. Guidelines should include the following considerations: setbacks, insulation, green roofs, landscaping, architectural screening.

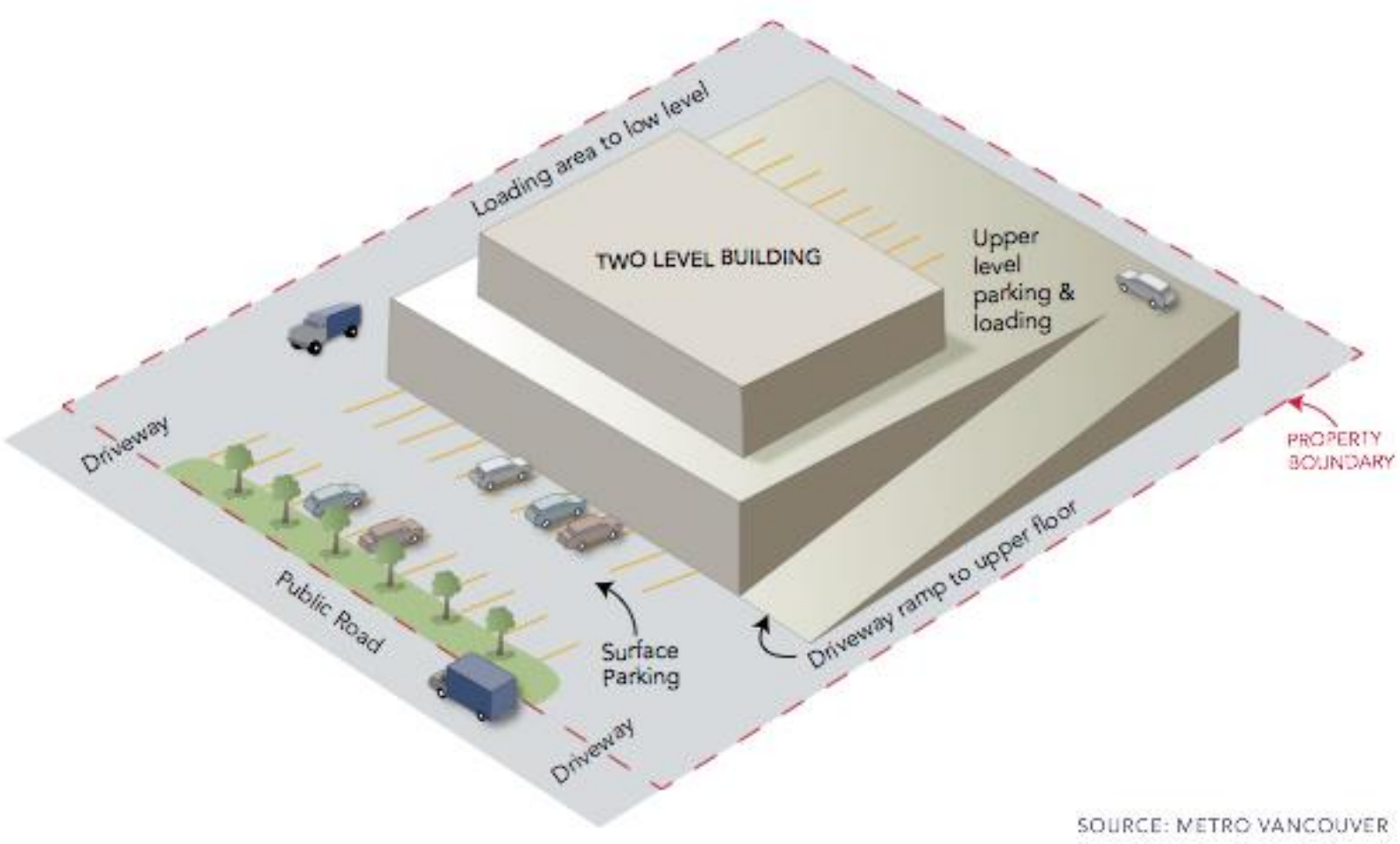

Figure 2: "A conceptual drawing of a higher density, multi-level industrial building with light industrial use and parking on the upper level" (Metro Vancouver, 2013). 


\section{CHAPTER 5: SITE BACKGROUND}

\section{The Creation of Industry in Rexdale}

Through the 1950s, the suburban development surrounding Toronto provided opportunities for industries to acquire cheaper (and often larger) lots of land than they would find downtown. Kerr \& Spelt (1958) observed that manufacturing employment grew by approximately 40,000 jobs between 1945 and 1950, nearly all of which were located in Toronto's new suburbs. While the former City of Toronto experienced a net loss of 514 plants, its surrounding suburban municipalities (e.g., Scarborough, Etobicoke) had a net gain of 815 plants (Kerr \& Spelt, 1958). The former City of Toronto's share of factory employment within the total metropolitan area decreased from 85 percent in 1950 to 67 percent in 1955 (Kerr \& Spelt, 1958). New suburban industry offered a chance for modernization, with large, one-storey facilities located with an appropriate setback (100 ft. from the road) and with well-landscaped lawns (Kerr \& Spelt, 1958). Newly-established industrial areas in the suburbs also provided the opportunity for local planning boards to implement stringent zoning requirements to separate residential uses from large swaths of land dedicated to manufacturing plants, warehouses, and wholesale establishments (Kerr \& Spelt, 1958). Furthermore, the availability of diverse land affordability options in the suburbs also attracted new industries (Kerr \& Spelt, 1958). Thomas (1968) also examined the industrial decentralization that occurred in Toronto, which prompted firms to locate outside the downtown core and in emerging suburbs such as Rexdale. The accessibility and proximity to "super-highways" (Highways 427, 401, 409) was noted as a key factor for

companies to establish themselves in Rexdale (Thomas, 1968, p. 156). Some 
push factors that resulted in suburban migration from downtown included: the need for expansion, traffic congestion, insufficient parking, building deterioration, and the desire for a brand new building (Thomas, 1968, p. 158). The decision of Simpson-Sears Ltd. to locate their warehouse in Rexdale also provided a draw for industries (especially smaller firms) to settle in the area. This is what Thomas refers to as a decision based on an "emulation" of Sears's decision to locate in Rexdale, rather than a "deliberate" or independent decision to do so (Thomas, 1968, p.158). The proximity to the airport also provided a significant draw for industries to locate in Rexdale as opposed to other developing industrial suburbs (Kerr \& Spelt, 1958, p. 16). However, it should also be noted that it was not feasible for all industries to relocate their facilities to the suburbs, which is why it was more common to find new industries establishing themselves in Rexdale (Thomas, 1968, p. 158).

Local developer Rex Heslop also played a critical role in the shaping of Rexdale's industrial character. In the early 1950s, Heslop was primarily involved in the residential development of Etobicoke's vacant land north of Highway 401. However, the debt-ridden Township of Etobicoke was unable to provide community services for these new neighbourhoods in the north end (Thomas, 1968, p. 207; Harris, 2015). This would unfortunately come to plague the Rexdale area for years to come, which many view as severely underserviced and isolated (Hepburn, 2012). As a result, Heslop was asked to put his subdivision development on hold and came to an agreement with the Township to established a ratio of 35 per cent industrial assessment to 65 per cent residential (Harris, 
2015). This would offset additional strains on the Township to provide services for exclusively residential areas (Thomas, 1968, p. 207). To attract manufacturers to places such as Rexdale, developers needed to incentivize the land by servicing roads and providing storm and sanitary sewers (Kerr \& Spelt, 1958). As historian Denise Harris notes, by 1953, 18 industries had committed to lots in Rexdale (Harris, 2015). The new residential subdivisions, which included diverse building stock (bungalows, highrises, townhomes, subsidized housing) also complimented the industrial developments by providing the much-needed labour force.

In their 2012 report Sustainable Competitive Advantage and Prosperity Planning for Employment Uses in the City of Toronto, Malone Given Parsons Ltd. identifies the importance of maintaining industrial employment districts. Most employment districts are located in Toronto's inner suburbs - the largest include Tapscott/Marshalling Yard in Scarborough, Rexdale and South Etobicoke, and the Highway 400 Corridor in North York. In 2015, office jobs accounted for 48.8 per cent of Toronto's employment, while manufacturing and warehousing had experienced an overall decrease of 24 per cent since 2005 (Malone Givens Parsons Ltd., 2012). Despite this decline, Core Employment Areas, which primarily consist of manufacturing activities, account for 63.4 per cent of all Employment Area jobs (Malone Givens Parsons Ltd., 2012). These Core Employment Areas are primarily located in Toronto's inner suburbs and provide crucial employment opportunities for residents in nearby Neighbourhood Improvement Areas (Malone Givens Parsons Ltd., 2012). Toronto's clusters of industrial employment areas provide "large contiguous areas for goods production, facilitating industry concentrations separated from sensitive uses with 
the City's borders" (Malone Givens Parsons Ltd., 2012). The proximity to large markets such as those in Southern Ontario, Quebec, and the United States mean Toronto's industrial areas are important for the City's economic vitality.

Since its inception in the 1950s, the Rexdale Employment Area (Figure 2) has remained largely centered around manufacturing, warehousing, and industrial uses. The district has morphed into one of the largest employment areas in the Greater Toronto Area, covers a total of 1,604 hectares (vacant and occupied), accounts for 11.5 per cent of Toronto's total industry inventory, and employs approximately 38,849 people (Malone Givens Parsons Ltd., 2012). With a net occupied land base of $1,177.6$ hectares, there is 32 million square feet of industrial building space in the Rexdale Employment Area (Malone Givens Parsons Ltd., 2012). To contextualize the importance of these figures, the Rexdale Employment Area employs a large number of people from bordering Neighbourhood Improvement Areas: Mount Olive-Silverstone-Jamestown, ElmsOld Rexdale, and Kingsview Village-The Westway. Figure 2 depicts the distribution of place of residence for those who work in the Rexdale Employment Area (Malone Givens Parsons Ltd., 2012, Appendix 3 D.2). More recent labour force data from the National Household Survey (2011) was used to generate the map in Figure 3, which supports that many residents of Rexdale are employed in the manufacturing sector. Certain pockets around Albion Road and Finch Avenue have proportions as high as 35 percent employed in manufacturing. 


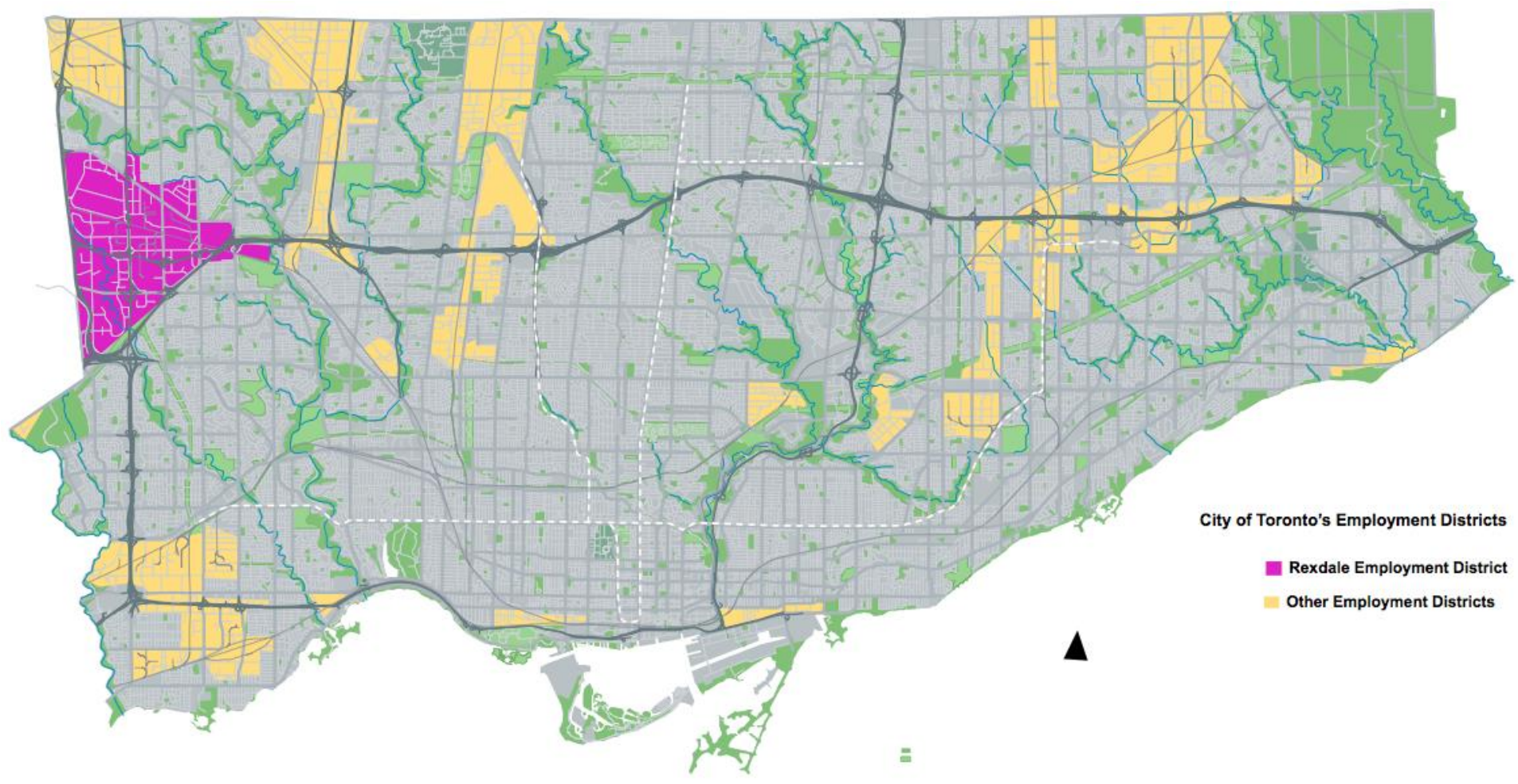

Figure 3: The City of Toronto's Employment Districts are primarily concentrated in its inner suburbs. 
Figure D.2.13: Distribution of Place of Residence for Employment in the Rexdale Employment District, 2006

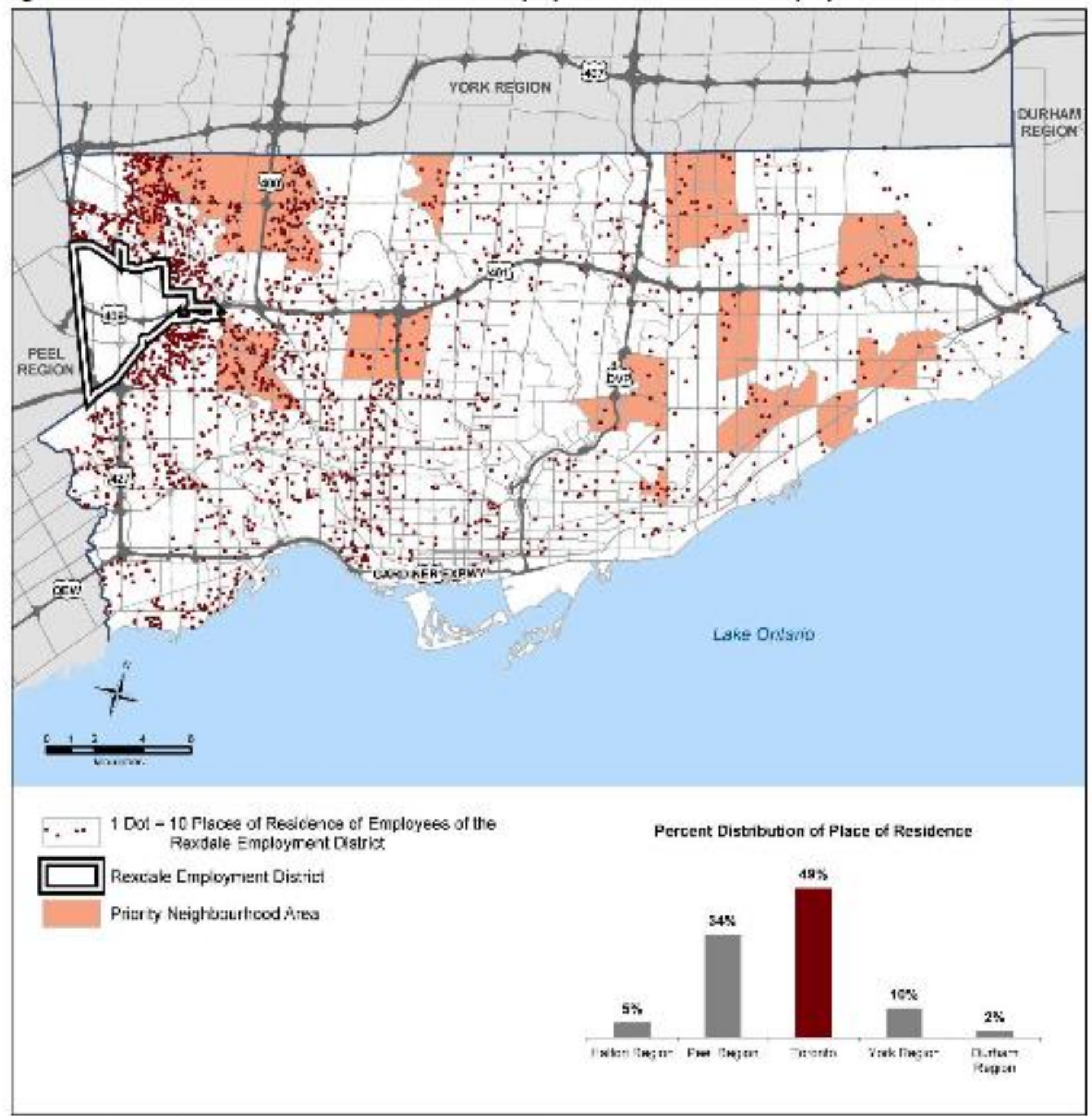

Source: Statistics Canado, Place of Work Stotus -2006 Census.

Figure 4: Most employees of the Rexdale Employment District reside in surrounding neighbourhoods. 


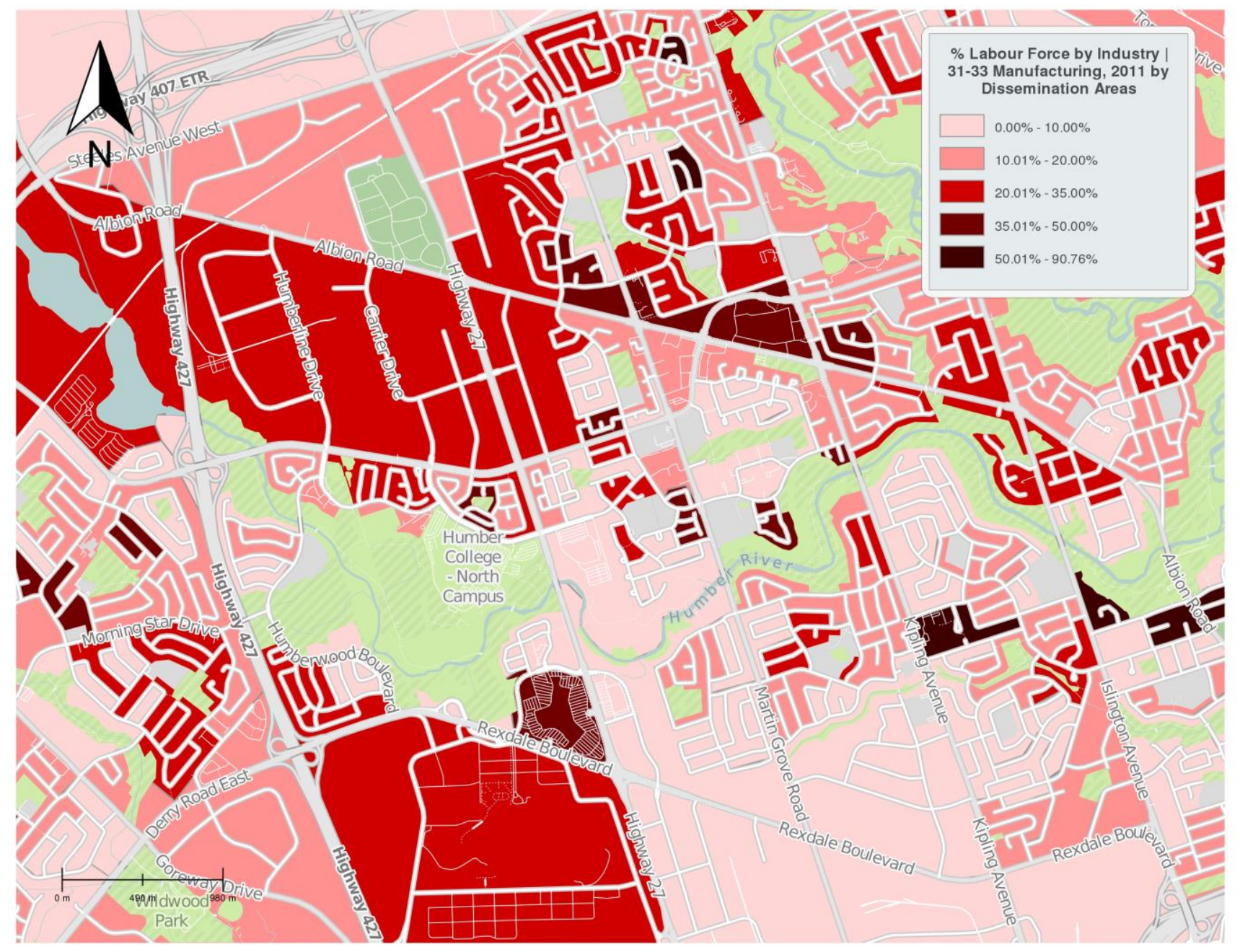

Figure 5: A high percentage of Rexdale residents are employed in the manufacturing sector.

A high concentration of employees of the Rexdale Employment District reside in the surrounding residential neighbourhoods that are commonly known as "Rexdale": Elms-Old Rexdale, Mount Olive-Silverstone-Jamestown, RexdaleKipling, Thistletown-Beaumond Heights, Kingsview Village-The Westway, and West Humber-Clairville. For simplicity, these neighbourhoods can be defined as 
Ward 1 and Ward 2 in North Etobicoke.

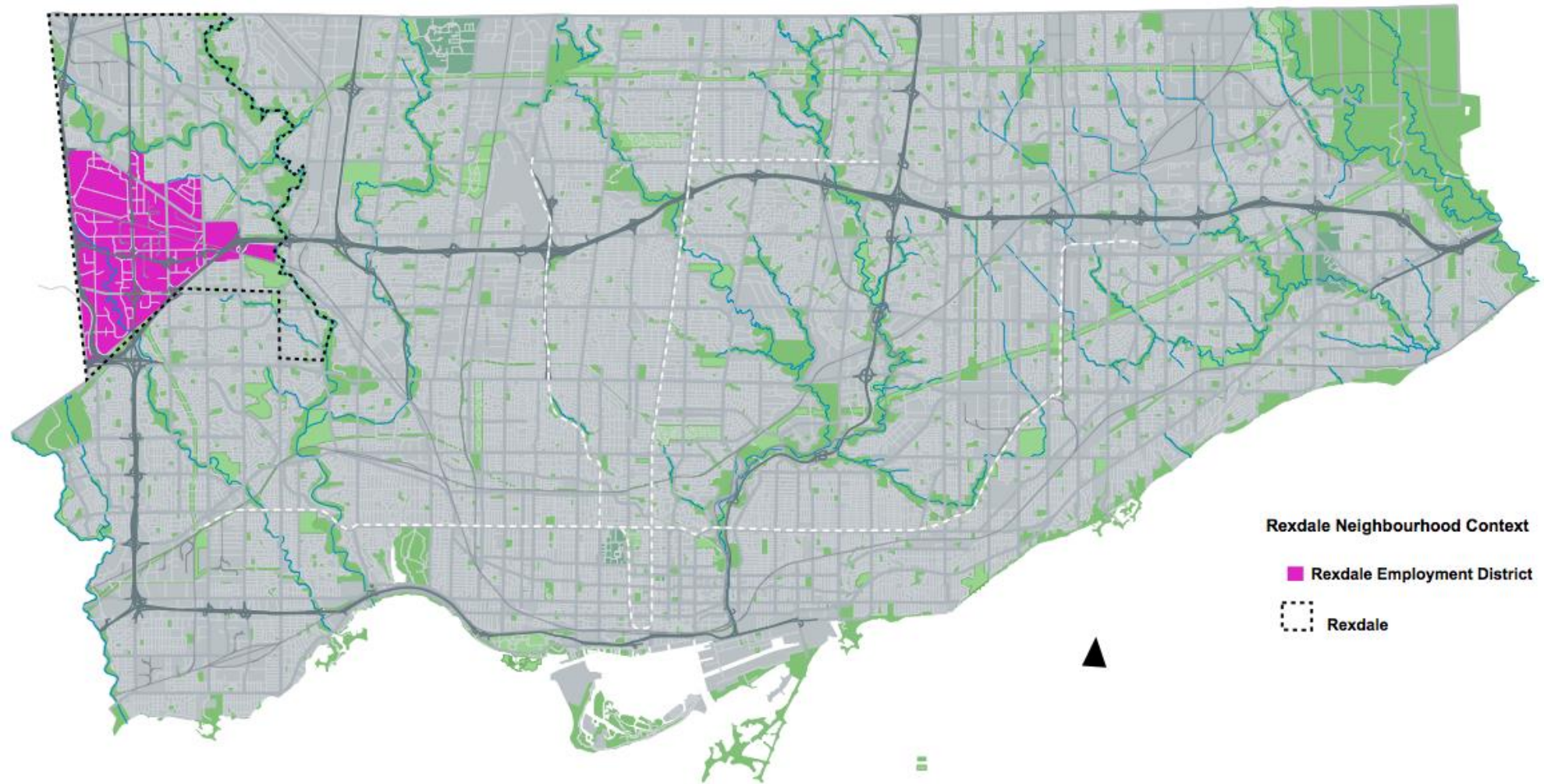

Figure 6: For this study, the Rexdale neighbourhood can be defined as the City of Toronto's Wards 1 and 2.

Some key Ward demographics (based on the 2011 National Household Survey) have been summarized in the table below.

\begin{tabular}{|l|l|l|l|l|l|l|}
\hline & $\begin{array}{l}\text { Total } \\
\text { population }\end{array}$ & $\begin{array}{l}\text { Recent } \\
\text { immigrants } \\
(2001- \\
2011)\end{array}$ & $\begin{array}{l}\text { No } \\
\text { certificate, } \\
\text { diploma, } \\
\text { or degree }\end{array}$ & $\begin{array}{l}\text { Unemployment } \\
\text { Rate }\end{array}$ & $\begin{array}{l}\text { Related } \\
\text { labour } \\
\text { force }\end{array}$ & $\begin{array}{l}\text { Low } \\
\text { income }\end{array}$ \\
\hline Ward $1^{*}$ & 60,920 & $39.8 \%$ & $25.6 \%$ & $12.8 \%$ & $34.5 \%$ & $21.9 \%$ \\
\hline Ward $2^{* *}$ & 55,170 & $28.9 \%$ & $25 \%$ & $10 \%$ & $25.3 \%$ & $19 \%$ \\
\hline
\end{tabular}

*Ward 1 includes the following neighbourhoods: West Humber-Clairville, Mount OliveSilverstone-Jamestown, Thistletown-Beaumond Heights, Rexdale-Kipling, and Elms-Old Rexdale.

**Ward 2 includes the following neighbourhoods: West Humber-Clairville, Kingsview Village-The Westway, and Willowridge-Martingrove-Richview.

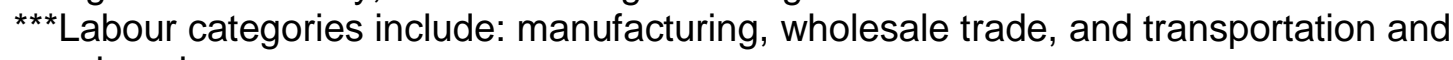
warehousing.

Although North Etobicoke is generally referred to as "Rexdale", the area 
actually consists of a number of smaller neighbourhoods, with names that reflect pre-development historic roots: Thistletown, The Elms, Smithfield (Jamestown). For the purposes of this paper, the neighbourhood of Rexdale will be considered Ward 1 and Ward 2, which includes all of the neighbourhoods that border the Rexdale Employment District. Rexdale is bordered by the City of Vaughan (Woodbridge) to the north, the City of Mississauga (Malton) and Lester B. Pearson International Airport to the west, Highway 401 to the south, and North York (Weston) to the east. The Humber River, one of the GTA's major waterways, meanders through the eastern portion of Rexdale and Etobicoke before emptying into Lake Ontario.

Neighbourhoods are often defined as a composite of the stories we tell. In popular (downtown) media, the story of Rexdale is one laden with negativity and stereotypes: a crime-ridden, poverty-stricken inner suburb of newcomers who blindly support former mayor and Ward 2 councillor the now departed Rob Ford (Heer, 2014). But there is a lot more to the narrative of Rexdale. A culturally diverse corner of Toronto, Rexdale is home to large South Asian and Black (Caribbean, East and West African) communities, as well as growing Middle Eastern and Latin American populations. With a high proportion of recent newcomers and incidences of low-income households, Rexdale is an area that has traditionally been underserved by community amenities and infrastructure. However, recent developments, such as the opening of the Rexdale Community Hub (2012) have increased awareness of the needs for community programming and support services. Developed by United Way Toronto, the Rexdale Community Hub is housed in a former high school and offers client-focused health, 
employment, legal and cultural services for the Rexdale community (Rexdale Community Hub, 2012). In addition to these crucial initiatives, Rexdale is an area that would benefit from meaningful and stable employment opportunities. The North Etobicoke Local Immigration Partnership (LIP) aims to assist newcomers' access to employment, as well as education, language, settlement services. In a presentation to LIP in 2011, the City of Toronto's John Alderdice (Manager, Business Retention \& Expansion) identified several strategies that should be implemented to encourage job growth in the City - some examples include: support entrepreneurship (small and mid-sized businesses), stimulate youth employment, use selective tax incentives in priority areas (Alderdice, 2011). Alderdice stressed that the City's Employment Areas are important sites for new investments and employment intensification, especially in order to accommodate a predicted job growth target of 1.64 million by 2031 (Alderdice, 2011).

\section{Rexdale Boulevard (Rexdale Boulevard \& Highway 27)}

As Toronto's inner suburbs developed and sprawled, land use compatibility issues became a concern for places like the Rexdale Employment Area. In 1985, the Woodbine Centre became Rexdale's second indoor shopping centre, providing much-needed commercial development and jobs for the community. The Woodbine Centre, at the northwest intersection of Rexdale Boulevard and Highway 27, is located just outside of the Rexdale Employment Area and "stimulated considerable interest and pressure for development of the approximately 60 hectares of vacant land in the immediate vicinity of Rexdale Boulevard and Highway 27 intersection" (City of Etobicoke, 1986). In their 1986 
study, the City of Etobicoke sought to design a land use plan for the area that would "promote and support a multi-functional centre", with the Woodbine Centre and nearby Humber College, Etobicoke General Hospital and the Woodbine Race Track as the cornerstones (City of Etobicoke, 1986). The City recommended that the remaining vacant lands in the vicinity, which includes subject site 555 Rexdale Boulevard, should be developed into a range of complimentary uses. As the City noted, the development of a major centre in this particular area would benefit a struggling working class Rexdale with new job opportunities, improved commercial and personal services, and inevitable improvements to public transit. However, the study also noted the concern of surrounding industries and the desire to avoid conflicts due to traffic generation (truck, employee, customer), operations (noise, night-time operation, spill-over lighting), outside storage, security and aesthetic concerns (City of Etobicoke, 1986, pg. 25). At the northern edge of the Rexdale Employment Area, this intersection plays a "transitional role" that accommodates a larger component of industrial activity than other multi-functional nodes in the City - the study concluded that the area's "multi-functional character will dictate that this industrial use be of high-order or high-quality nature" (City of Etobicoke, 1986, pg. 25). Thus, the City's impetus to develop the vacant lands near this transitional intersection (e.g., 555 Rexdale Boulevard) centered around the premise of establishing a major corridor for employment, commercial, and institutional uses. 


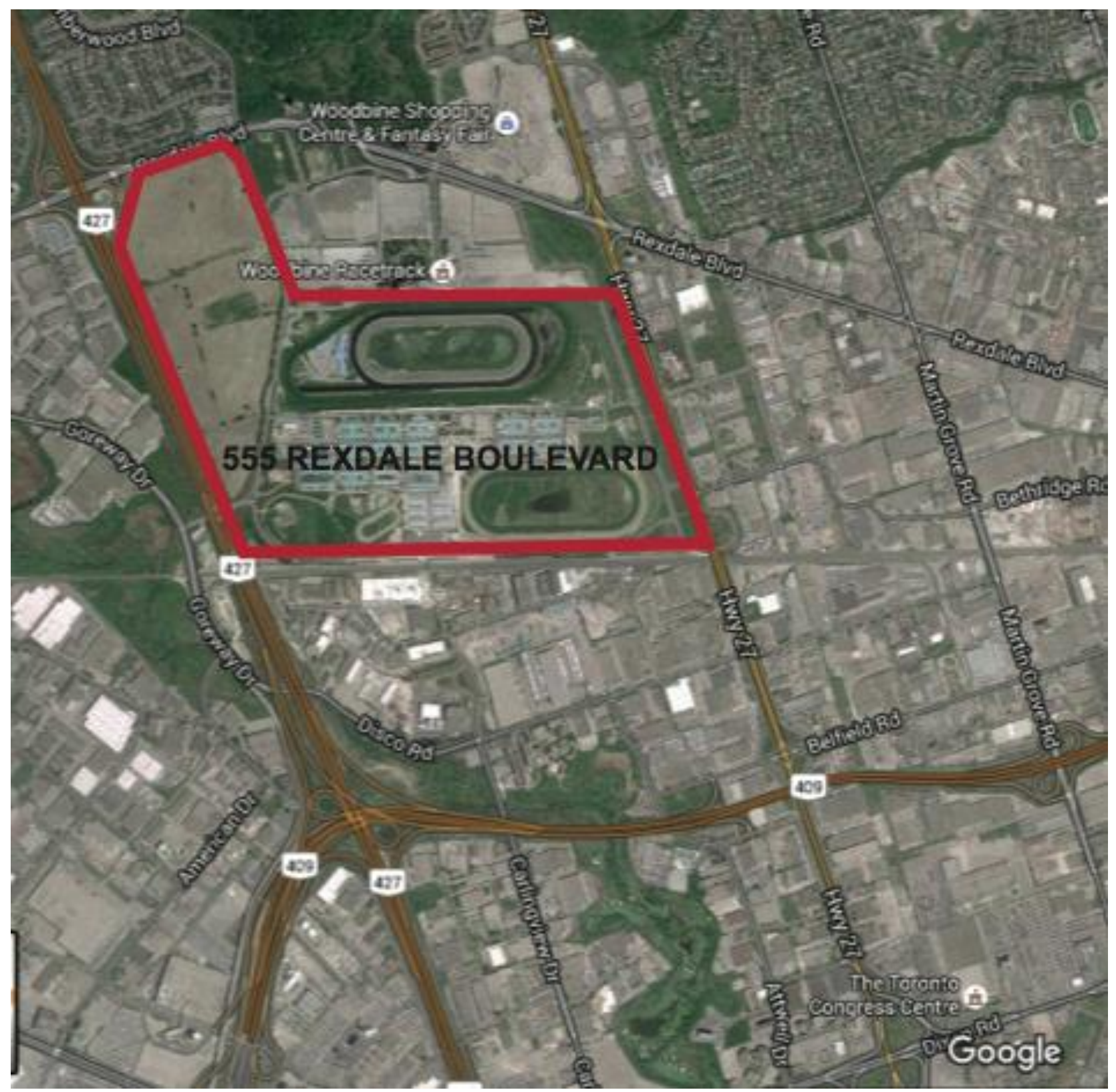

Figure 7: The lands owned by the Woodbine Entertainment Group at 555 Rexdale Boulevard. This entire site is set to be developed. 
Thirty years later, the land around Rexdale Boulevard and Highway 427 is slowly developing - although much of it remains vacant. There are three highrises along Rexdale Boulevard, just west of the Woodbine Centre. A strip plaza now provides a gateway into Humberwood Boulevard, and larger, big box-style plazas along Queens Plate Drive. The Woodbine Centre has declined since its heyday in the late 1980s and now has a high number of vacancies, which has only been exasperated by the closing of two major anchor stores, Zellers and Sears. The major draw to the area appears to be the Woodbine Racetrack across the street, which primarily attracts an older demographic who use the gaming facilities.

In February 2016, the Woodbine Entertainment Group and Trinity Development Group entered into a partnership to develop the vacant land adjacent to the Woodbine Racetrack, at 555 Rexdale Boulevard (Lenti, 2016). As reported, the lands will be developed into an entertainment complex with a 15,000-square-metre venue that would seat up to 5,000 (Lenti, 2016). In operation in Rexdale since 1961, the Woodbine Racetrack currently hosts 3,000 slot machines and generates a hosting revenue of $\$ 15$ million per year for the City (Herhalt, 2016). While interest in horse racing has been waning over the past decade, the Woodbine Entertainment Group hopes extended gaming facilities can help attract new interest to the venue (Herhalt, 2016).

Much of the current discussions surrounding the development of 555 Rexdale Boulevard mirror those from the late-1980s studies mentioned above. That is, there has been ongoing interest from developers (and the Woodbine Entertainment Group) to transform this vacant site into a mixed-use, multifunctional node. This culminated into Woodbine Live!, a billion-dollar 
development and partnership between the Woodbine Entertainment Group and the Cordish Group (Ladha, 2012). The project, which was approved in 2007, would include two phases that would transform this corner of Rexdale into a major entertainment and tourist destination. Woodbine Live! was also touted by then-Ward 2 Councillor Rob Ford as having the capability of turning Rexdale "into Rosedale" (Alcoba, 2013). It was reported that the development would create an estimated 9,000 new jobs for the area, primarily in the service industry (Shephard, 2013). The first phase of the project would feature hotels, restaurants, a skating rink, a theatre, and other retail-related uses (Shepard, 2013). The second phase was to feature residential and office development on the remaining lands. The various permitted land uses that were a part of the Woodbine Live! project (in particular, residential and retail) signified the potential for a major shift in development within employment areas such as the Rexdale Employment Area. That is, Woodbine Live! was poised to become a major land-use planning precedent for an area that is still largely industrial and could have seriously disrupted existing employment uses.

Woodbine Live!, however, never materialized. The lands remained vacant for years after the project announcement and in 2013, the partnership between the Woodbine Entertainment Group and the Cordish Group ended (Shepard, 2013). While the Woodbine Entertainment Group began seeking a new partner to keep the project afloat, the City began reassessing its policies surrounding employment lands. By the early 2000s, the City of Toronto was processing several development applications that sought to rezone employment lands to 
mixed use or commercial and residential uses. These applications were especially prevalent in high-demand areas of the city, such as Liberty Village.

As part of their municipal comprehensive review, the City reviewed requests to convert employment lands. In total, the City examined 146 conversion requests and provided final assessments and recommendations based on longterm employment planning rationales (City of Toronto, 2014; City of Toronto, 2013). This included criteria based on the Growth Plan, the PPS, and Official Plan policies. The site at 555 Rexdale Boulevard was included in this review and it was recommended that the lands be retained as Employment Areas and designated as Core Employment Areas (City of Toronto, 2013). The original request to convert the lands to Mixed Use Areas would permit "residential uses for a southern portion of the property" that is just outside the Airport Operating Area (City of Toronto, 2013). In their planning rationale, the City mentioned that while Toronto is poised to meet Provincial employment forecasts, multiple zoning conversions could impact Toronto's ability to meet those targets (City of Toronto, 2013). Industry perspectives also influenced the City's decision and staff noted that the conversion of 555 Rexdale Boulevard would "adversely affect the overall viability of this part of the Rexdale employment area" (City of Toronto, 2013). This is primarily due to the introduction of sensitive uses: local industries "expressed concern over the introduction of both residential and non-residential sensitive uses in or near employment lands" (City of Toronto, 2013). The sensitive uses would ultimately lead to land use conflicts, especially since many of the surrounding industries operate 24 hours a day, 7 days a week (City of Toronto, 2013). Finally, Ministry of the Environment intervention is costly to industries, who would be 
forced to comply to noise and air abatement standards. Residential development on this site would also not be viable from a community perspective, as it is isolated from necessary community amenities and services such as parks, schools, and recreation centres.

It should be recognized, however, that Site and Area Specific Policy (SASP) No. 296 allows for residential uses at the southeastern corner of Rexdale Boulevard and Highway 427. This is due to the fact that there is already existing residential development across the street, on the north side of Rexdale Boulevard. In their original proposal, the developer of 555 Rexdale Boulevard indicated that residential uses would be located at the south east portion of the site, which staff note is in close proximity to heavy industrial uses and does not provide a sufficient buffer (City of Toronto, 2013).

Since this review process, there have been ongoing discussions about how the vacant land at 555 Rexdale Boulevard should be developed. When the City introduced the idea of hosting a new casino, the Woodbine Entertainment Group again expressed interest in expanding its gaming facilities. In 2015, the City approved the expansion of the Woodbine Racetrack into a full-fledged casino, which would also introduce hotels, conference centres, and other uses to the site. 


\section{CHAPTER 6: RESULTS \& DISCUSSION}

This section is informed by one-on-one interviews with the representatives of the following stakeholder groups: City of Toronto planners, employees in the Rexdale Employment Area, industry association representatives in Toronto, and community organization representatives in Rexdale. The findings from these interviews can help shape community and planning policies of the long-term vision and provide perspectives that are currently missing from the literature. Interview questions were designed based on the stakeholder category. Potential interviewees were identified through online research and then were contacted via email. While the intent was to interview with eight stakeholders (two people per category), only a total of five interviews were conducted. These included two planning professionals, one Rexdale Employment Area employee, one industry association representative, and one community organization representative.

\section{Planning perspective}

Through OPA 231, the City of Toronto has developed planning policies to more actively protect employment lands from encroaching sensitive uses and to encourage and create more manufacturing jobs. Both planners cite the proximity to the airport as one of Rexdale's biggest assets and key features. Although the Rexdale Employment Area is in a suburban location, both planners confirmed that the District experiences similar development pressures as downtown (but not at the same volume). One planner described having developers inquire about land in areas like the Rexdale Employment Area, interested in developing non-employment uses. As this planner noted, developers often fail to see the larger picture of the future of employment in Toronto. Many 
developers are under the impression that "manufacturing is dead" and that the lands should be used for something more lucrative. While these conversations with developers do occur, both planners reiterated that the City's tight land-use controls on employment lands would make it near impossible to alter the industrial character of the Rexdale Employment Area.

The "branding" of employment districts is seen as a logical next step to attract both employers and a new generation of labour. One planner noted that while employment planning polices offer strong protection, the City must develop creative strategies to market their employment districts to younger generations. To do so, the City needs to understand what millennials want to see in a job, what kind of workspace they want to be in, and what sectors interest them. These findings can ultimately direct the City to more efficiently plan for more innovative employment districts. For example, younger people transitioning into the labour force may wish to work close to transit. In response to this demand, the City should continue to work on providing diverse and accessible public transportation options to employment districts, especially those currently located far from existing TTC subway lines. With a number of local college programs providing students with hands-on experience in trades, the City has the potential labour force to continue to support manufacturing districts.

Additionally, developers need to be encouraged to produce more flexible designs, instead of the conventional one-storey industrial unit. This can be done through financial incentives from Economic Development (such as the City's Imagination, Manufacturing, Innovation, Technology (IMIT) Incentive Program), or by developing zoning policies to accommodate these multi-functional employment 
uses. As discussed in the Metro Vancouver case study, multi-use manufacturing buildings could house different functions, from lighter, small-scale companies to larger-scale, more established industries. This flexible design model would appeal to the younger generations, many of whom are becoming interested in smallerscale manufacturing opportunities such as crafts, textiles, and woodworking. Furthermore, revisiting the architectural design of these facilities can help create an image for the district that helps with the branding. Similarly, the creation of a Rexdale industrial association (similar to the South Etobicoke Industrial Employers Association) would play a role in developing the brand of the District and maintaining a marketing-focussed presence. Both planners also thought that while a Rexdale industrial association could help unify the employers in the area to mitigate future development pressures, industrial districts also require strong political support from councillors for a secure future.

\section{Industrial representatives}

Both the Rexdale Employment Area employee (REA employee) and the industrial association representative (industrial representative) discussed their experiences with the South Etobicoke Industrial Employers Association (SEIEA), a group that promotes the retention and growth of industry in South Etobicoke. SEIEA was established in the late 1980s in response to plant closures and the rezoning of prime industrial land in South Etobicoke to residential - there was a concern that a residential development would ultimately force the remaining industries to also leave the area. As part of their mandate, SEIEA represents the interests of industries in South Etobicoke and advocates the importance of longterm, sustainable land-use policies for the City's industrial uses (South Etobicoke 
Industrial Employers Association). Throughout the 1990s, SEIEA became the voice for South Etobicoke industries in land-use planning issues. During the time of amalgamation, the City undertook a zoning by-law harmonization process, which threatened to remove some of the rights of companies located in certain industrial areas such as South Etobicoke. In response, SEIEA assisted local industries in the appeal process.

Similarly, SEIEA was involved in the OPA 231 process by providing the industry perspective and participating in consultation sessions with City planners. Both the REA employee and the industrial representative found that industry participation in the OPA 231 process strengthened support for employment areas and this is evident in the resulting polices that provide more stringent protection of employment lands. However, the REA employee noted that while the City's official stance is to not convert key employment lands, political pressures can sometimes deter these protective policies. Politics across Toronto often changes by neighbourhoods and City councilors have their own specific objectives and goals depending on the interests of their constituents. As a result, councilors will promote their own "pet projects" that may require the conversion of employment lands to other uses. While the councilor may view their project as an "exception", they certainly add up across the City. The impact of approving just a small number of rezoning applications has the potential to undermine employment land retention: "When one company sees that they didn't get their conversion approved, they'll go to the OMB and go look, 'They approved that one and that one, but why not ours?'" (REA employee, 2016). Since there are no standard processes or measures in place to evaluate a conversion request, the rationales 
for approving a conversion request versus not approving an application are sometimes unclear and arbitrary. For example, the opening Planning Rationale paragraph in the 555 Rexdale Boulevard decision states:

The existing supply of Employment Areas is sufficient to meet the 2031 Provincial employment forecasts in Toronto and it is anticipated that the City will meet the employment forecasts allocated to the municipality pursuant to the Growth Plan. It should be noted however that while no single conversion request would affect this outcome, multiple conversions could impact Toronto's ability to meet the Provincial employment forecast. (City of Toronto, 2013, p. 369)

While the City claims that the approval of a single conversion request will not affect Provincial employment forecasts, it does not specify how one conversion request may be more favourable over another.

Both the REA employee and the industrial representative also confirmed that the perception of manufacturing as a declining sector has impacted discussions surrounding employment lands:

There's the impression that in the new economy, there aren't as many jobs in manufacturing and that the 'sexy' industries are IT, high tech and software development... but not everyone can work in those sectors. There's a new for all types of employment. (Industrial representative, 2016)

With these 'flashier' IT sector jobs being perceived as more favourable and lucrative, the image of manufacturing is affected. However, the industrial representative notes that a steady job in manufacturing can pay just as well as other sectors and offer a stable, secure livelihoods for employees. Furthermore, a diverse economy is needed to tap into different skill sets, interests and capabilities.

From an industrial perspective, there are no major concerns with the proposed 
Woodbine Racetrack expansion and entertainment complex. The site itself is located on the periphery of the Rexdale Employment Area, between the racetrack and Highway 427. Due to its location, the REA employee does not think introducing an entertainment tourist area to this site would interfere with nearby industrial functions. There is concern, however, about traffic impacts. Due to the size and scale of the proposed development, the expanded casino is expected to have a regional draw. This increase of traffic may not be compatible with the existing truck traffic generated by the Rexdale Employment Area (Industrial representative, 2016). The very function of the employment district depends on the ease of transporting goods into and out of the plants, as well as employees being able to get into work. The developer and the City would need to be proactive to mitigate this potential issue and explore transit options such as including a new highway exit on the 427 for the new development (REA employee, 2016).

While the current proposal for 555 Rexdale Boulevard does not include residential uses, it should be noted that hotels will be a part of this development. From the REA employee's perspective, the hotel component is a non-issue, as there are already a number of hotels already located on the periphery of the employment district, especially west of Highway 427 and north of Belfield Road. The prevalence of hotels in the area appears to be a unique characteristic of the Rexdale Employment Area and is likely due to the proximity to the Pearson International airport. The REA employee reasons that the introduction of other sensitive uses - such as daycares, schools and places of worship - create more of a threat to industrial districts, as the Ministry of the Environment are then required 
to impose noise and emissions restrictions on surrounding industries. Conversely, the industrial representative believes that overnight establishments such as hotels are possible impediments to surrounding industrial uses, as they are "one step below a residence" (Industrial representative, 2016). Due its similarities to residential uses, a hotel may set the precedence for further non-employment development in the area. Furthermore, the industrial representative wonders if the proposal demonstrates the best and most efficient use of the vacant land: "There's lost value. There's no other land that close to the airport that's undeveloped. So should it be used for uses that leverage the airport more?" (Industrial representative, 2016). As he proposes, there needs to be more consideration for specific site context and land-use compatibility with adjacent industries. To address these issues, the industrial representative thinks it might be possible for the developer to introduce a hybrid of uses, both with entertainment (casino, retail, restaurants) and industrial uses. With the entertainment complex on the edge of the site, the industrial component could be developed on the east side of the land and transition into the heavier industries into the Rexdale Employment Area. This sort of compromise reflects OPA 231's policies surrounding 'General Employment' and 'Core Employment', which recognize the need to systematize the diverse uses found within and around employment areas.

\section{Community organizations}

The community organization representative emphasized the importance of creating job opportunities for the Rexdale community, which suffers from a high unemployment rate (12.8 percent versus the City's average of 9.3 percent) (NHS 
2011). In her snapshot of the community, the community organization representative noted that precarious employment especially affects three groups in Rexdale: youth, women, and seniors. With high drop-out rates and pressures to help support their families, youth are likely only able to attain part-time or seasonal work and are restricted from meaningful employment. Women and seniors, especially in newcomer populations, are often relegated household and childcaring tasks within the confines of the home. This only restricts these populations from accessing local services (language, health care, etc.), but also employment opportunities.

Employment opportunities should also reflect the skill set of the local population. Increasingly, many newcomers are internationally trained and educated and seek employment in the same profession they had in their home country. However, most are unable to use their skills and instead find work in manufacturing and service sectors. The community organization representative also notes that many of these jobs are part-time, so newcomers often work two to three jobs at a time, which further limits their abilities to transfer their international experience to the local workforce. An additional trend is that more Rexdale residents are having to work outside their community and commute long hours to their place of employment.

According to the community organization representative, the 555 Rexdale Boulevard development has the opportunity to create jobs for local residents, especially youth. Considering the size of the lot, the interviewee believes some of the property could be allocated to community space for local needs. With an increasing concern for food security in the City, it may be valuable to use some of 
the vacant land at 555 Rexdale Boulevard for food-growing initiatives or a community garden. This would increase Rexdale residents' access to locally grown foods. However, in order to secure youth employment or a local community space, a community benefits agreement must be established.

Almost 10 years ago with a previous proposal for 555 Rexdale Boulevard, an advocacy group known as CORD (Community Organizing for Responsible Development) was in negotiations with the Woodbine Entertainment Group to secure up to 10 percent of employment generated from the development for local residents. In addition to access to stable, unionized jobs, CORD also advocated for "employment training, affordable housing, better public transit, more child card and community space" as part of the large-scale development (Monsebraaten, 2007). The community organization representative believes something similar to CORD should be replicated for the upcoming development of 555 Rexdale Boulevard and wants policies implemented to support such endeavours that hold developers accountable for holding up their end of the deal. She noted that there is an interest in developing community benefits agreements and that "residents want to mobilize around these issues, ensure their voices are being heard, and understand how they contribute to that agreement". 


\section{CHAPTER 7: RECOMMENDATIONS, NEXT STEPS, \& VISION}

The following recommendations and next steps are derived from the literature review, the case studies, and the interviews with key stakeholders. These recommendations should be considered the foundation for a long-term land-use plan for the Rexdale Employment Area. The strategies and action items listed here will ensure the viability of the employment district, by providing directives for both the City and developers. While these recommendations have been created specifically for the Rexdale Employment Area, they may be applied to other industrial hubs in Toronto's inner suburbs that experience similar development pressures.

\section{Establish a Rexdale Industrial Association}

An industrial advocacy association is required in order to mobilize in response to inevitable development pressures. The association would have the mandate to protect both Core and General Employment lands in the Rexdale Employment Area and also encourage innovation and growth. That is, the association must be proactive rather than reactive and develop strategies to attract new industries, and diversify manufacturing uses. The association would be active in the brand marketing of the Rexdale Employment Area.

The association should have distinct objectives from nearby neighbourhood associations and Business Improvement Areas (BIAs), which tend to be more retail and residential focused. The association should, however, work collaboratively with them to retain employment in the area. In the interview with the industrial association representative, it was noted that establishing an industrial association is difficult (due to the focus on business operations). To 
facilitate the Rexdale Industrial Association, it is recommended that the SEIEA include a Rexdale employer representative on its Board. This would be beneficial for both parties, as the Rexdale and South Etobicoke Employment Areas face similar issues.

\section{Brand the Rexdale Employment Area}

The branding strategy would be a precursor to the City's Secondary Plan for the Rexdale Employment Area. To develop the brand, the City must engage all relevant stakeholders: employers in the Area, industrial associations in Toronto, planners, residents, and developers. In addition to market research on employment trends, consultation meetings and design charrettes with stakeholders must be completed. The strategy must demonstrate a thorough understanding of new trends in the manufacturing sector and competition, as well as focus on bringing innovation to the Rexdale Employment Area. The strategy should tap into new technologies in manufacturing and should position the brand to appeal to millennials in the workforce, the introduction of light manufacturing uses (bakeries, textiles, woodworking, crafts). Part of the strategy, for example, will be to develop a strong online presence through social media, communications materials, and advertising. The Rexdale Industrial Association should play a role in the brand creation and should implement marketing strategies as part of its overall objectives. Consultation with Toronto MADE may help understand the dynamics within small-scale local manufacturing and how to target that sector.

\section{Flexible zoning and design policies}

OPA 231 Amendments specify land uses and restrictions for Core and General 
Employment lands. These land-use specifications must be developed into a robust policy framework that reimagines employment districts for manufacturing's future. Policies should allow individual businesses to integrate other, related uses in co-business functions. Stakeholder discussions acknowledged lengthy and costly Site Plan Approval and Minor Variance processes should be revisited for industrial districts, in order to make it more plausible and feasible for businesses to instigate multi-uses on their properties. Co-working spaces must be encouraged.

Similarly, design guidelines for the Rexdale Employment Areas need to be developed. As the manufacturing sector transforms with new technologies, developers must be able to respond by providing adequate and flexible work space so that buildings can be adapted to the type of manufacturing. Instead of the conventional one-storey building with sprawled out parking, intensification should be encouraged (where possible). Other considerations will include: landscaping, setbacks, branding, and the locations of auxiliary uses such as restaurants and retail in General Employment zones.

\section{Community Benefits Agreements}

A local community-based organization should be initiated to address Community Benefits Agreements (CBAs) with potential developers. The developer of 555 Rexdale Boulevard, as well as any future developers siting their work in Rexdale, must engage with local residents groups to determine whether a CBA should be established. CBAs should specify the percentage of jobs to be allocated for local residents, as well as other negotiated community benefits or enhancements provided by the developer. This could include the developer 
establishing a Community Liaison Committee to mediate throughout the development process, or setting up a Community Vibrancy Fund, which would set aside funds towards community projects and initiatives.

The Toronto Community Benefits Network, a community-labour partnership, recently worked with Metrolinx to create a CBA for local residents to have access to jobs and training opportunities on the Eglinton Crosstown project. It should be noted that an organization known as MyRexdale is hosting a Community Benefits Co-Design on April 28, 2016, to initiate discussions around CBAs for the Woodbine gaming expansion, as well as the proposed Finch West LRT.

\section{Investing in education}

Provide educational opportunities for youth to develop the expertise and skillset to transition into the workplace. Manufacturing-oriented curriculum can introduce youth to technologies and technical tools (such as 3D printing, robotics, or highly specialized food production) that are increasingly in demand in the changing workforce (DEEP Centre, 2015). Students can then use these much sought-after skills to participate in work placements at local industries and businesses. Techsdale is a local mentorship program that teaches youth techsavvy skills such as game coding, graphic design, and website development (Techsdale, 2016). With the help of mentors and business partners, this program provides Rexdale youth with the opportunity to acquire the in-demand skills needed for growing gaming and technical industries, while also fostering a sense of entrepreneurship. 


\section{A Vision for the Rexdale Employment Area}

Rexdale will likely not face the same kind of development pressures as employment lands closer to Downtown Toronto. Geographically, Rexdale cannot be easily gentrified, as it barely registers in the imagination of the urban creative class and young hipsters. However, as discovered through research and the OPA 231 scan, the conversion of employment lands is an issue that especially affects inner suburban neighbourhoods. These neighbourhoods typically have lower incomes, less access to public transit, and would benefit from more meaningful employment opportunities within their community.

The vision for the Rexdale Employment Area is the marrying of manufacturing and community. The aforementioned recommendations and next steps are examples of what can be implemented in the Rexdale Employment Area to retain its character as a manufacturing district for the community. However, this research has indicated that the role of manufacturing in the City is poised to change. The way we produce goods is changing, with the introduction of new technologies, such as 3D printing, nanomanufacturing and in food production. These types of industries should be encouraged to locate within the Rexdale Employment Area, but only if this is coupled with increasing educational and training opportunities for the local community. In addition to integrating more hands-on, technology-based education within the school curriculum, developers entering the Rexdale Employment Area need to engage in a CBA for local residents. This means ensuring there is a labour force within the community that is capable and trained to work in these new industries. These will result in better-paying and more stable employment than the part-time work that is available in the service sector. 
The public transit system within Rexdale should be reassessed to include more direct and express routes to the Rexdale Employment Area for local residents, which would not only reduce dependency on the car, but will also increase accessibility of the area. This relates to the idea of leveraging underutilized properties within the Employment Area for community initiatives, such as gardens or even developing a partnership with Humber College to use the spaces for training workshops. Similarly, co-working spaces (enabled through more flexible land-use policies) can be established within large-scale industries to introduce light manufacturing uses. With a growing spirit of entrepreneurship in Rexdale, these uses can be community-owned, tapping into the knowledge, skills and expertise within the community.

The proposal to develop 555 Rexdale Boulevard into a tourist destination with a full-fledged casino with restaurants, retail and hotels does not represent the best use for the land. While the concerns raised during stakeholder interviews were minimal, there is still the need to address how this development will translate into meaningful employment for residents. While it is being touted that a development of this scale will generate thousands of jobs, many of these could be part-time and seasonal service work that do not pay very well. This development could also set a precedent for more non-industrial uses within the Rexdale Employment Area or in the vicinity, which could seriously affect the operations of local businesses.

It makes sense that the Woodbine Entertainment Group would want to expand its gaming facilities, especially to attract more visitors beyond the senior populations. However, it is recommended that the developer scale back the 
proposal and seek community input in the site plans and other potential uses for the property. Given that this the last large piece of vacant land within their community, Rexdale residents should help shape the development for their own needs. What kind of employment opportunities would Rexdale residents like to see on this property? Similarly, the Rexdale Industrial Association should be consulted in development discussions and any design charrettes. In order to offset any inadvertent harm to the nearby employment uses, a section of the property can be allocated for industrial uses that would provide a buffer between the casino and the rest of the Employment Area. 


\section{REFERENCES}

Alderdice, J. (2011). Economic Trends, Issues \& Directions: North Etobicoke LIP Summit. [PowerPoint slides]. Retrieved from http://slideplayer.com/slide/5900893.

Blais, P. (2015). Planning for Prosperity: Globalization, Competitiveness, and the Growth Plan for the Greater Golden Horseshoe. Toronto: The Neptis Foundation.

Camiros, Ltd., Applied Real Estate Analysis, Inc. and Sonoc/Hutter/Lee Ltd. (1998). Kinzie Industrial Conservation Area Tax Increment Redevelopment Plan and Project. Prepared for: the City of Chicago.

Catungal, J.P., Leslie, D. and Hii, Y. (2009). Geographies of displacement in the creative city: the case of Liberty Village, Toronto. Urban Studies, 46(5\&6): 1095-1114.

City of Chicago (2014). "Fulton Market Innovation District: A plan to coordinate economic growth, preservation, design, and public improvements" Prepared by Chicago Department of Planning \& Development.

City of Etobicoke (1986). Rexdale Boulevard-Highway 27 complementary land use study.

City of Toronto. (2013). "Final Assessments of Requests to Convert Employment Lands." Prepared by Toronto's City Planning division.

City of Toronto. (2014). "Conversion Requests". Prepared by Toronto's City Planning division.

City of Toronto Zoning By-Law No. 1714-2013. (Enacted, December 18, 2014). Obtained from: http://www.toronto.ca/legdocs/bylaws/2013/law1714.pdf.

City of Toronto (2016). Rexdale Neighbourhood Context. [ESRI shapefile].

Clavel, P. and Giloth, R. (2015). Planning for Manufacturing: Chicago after 1983. Journal of Planning History, 14(1): 19-37.

DEEP Centre. (2015). The Future of Manufacturing in Ontario: New Technologies, New Challenges and New Opportunities. Toronto: DEEP Centre.

Duany, A., Speck, J. and Lydon, M. (2010). The Smart Growth Manual. New York, NY: McGraw-Hill Education.

Fitzgerald, J. and Leigh, N.G. (2002). Economic Revitalization: Cases and Strategies for City and Suburb. London: SAGE Publications.

Harris, D. (2015, May 7). Rexdale community, industry built on the back of one man. Etobicoke Guardian. Retrieved from http://www.insidetoronto.com. 
Harris, R. (2004). Suburbanization and the Employment Linkage. In R. Lewis (Ed.), Manufacturing Suburbs: Building Work and Home on the Metropolitan Fringe. Philadelphia: Temple University Press.

Heer, J. (2014, February 13). The Divided City: Rexdale isn't perfect, but I prefer it to the hypocrisy of downtown. Toronto Life. Retrieved from torontolife.com.

Hepburn, B. (2012, June 27). Rexdale hub a beacon for area hurt by poverty and crime. The Star. Retrieved from http://www.thestar.com.

Herhalt, C. (2016, February 16). Woodbine Racetrack plans to build new concert hall. cp24. Retrieved from http://www.cp24.com.

Kerr, D. and Spelt, J. (1958). Manufacturing in Suburban Toronto. The Canadian Geographer, 3(12): 11-19.

Ladha, R. (2012, March 27). What happened to Woodbine Live? BlogTO. Retrieved from www.blogto.com.

Leigh, N.G. and Hoelzel, N. (2012). Smart Growth's Blind Side. Journal of the American Planning Association, 78(1): 87-103.

Lenti, E. (2016, February 16). New Proposal Could Bring Entertainment Venue to Woodbine Racetrack. Torontoist. Retrieved from torontoist.com.

Lewis, R. (2004). Industry and the Suburbs. In R. Lewis (Ed.), Manufacturing Suburbs: Building Work and Home on the Metropolitan Fringe. Philadelphia: Temple University Press.

Malone Given Parsons Ltd. (2012). Sustainability Competitive Advantage and Prosperity - Planning for Employment Uses in the City of Toronto. Obtained from: http://www.cbc.ca/toronto/features/stuckintraffic/docs/sustainable.pdf.

Metro Vancouver (2011). "Metro Vancouver 2010 Industrial Lands Inventory". Prepared by Metropolitan Planning, Environment and Parks.

Metro Vancouver (2012). "Best Practices for the Intensive Use of Industrial Land". Prepared by Metropolitan Planning, Environment and Parks.

Metro Vancouver (2013). "Opportunities for the Intensive Use of Industrial Land".

Ministry of Infrastructure. (2006). Growth Plan for the Greater Golden Horseshoe, 2006. (Office Consolidation, June 2013). Obtained from:

https://www.placestogrow.ca/content/ggh/2013-06-10-Growth-Plan-for-the-GGH-EN.pdf.

Ministry of Municipal Affairs and Housing. (2008). Planning for Employment in the Greater Golden Horseshoe. Obtained from: 
https://www.placestogrow.ca/index.php?option=com_content\&task=view\&id=366\&ltemid $=15$.

Ministry of Municipal Affairs and Housing. (2014). Provincial Policy Statement. Obtained from: http://www.mah.gov.on.ca/AssetFactory.aspx?did=10463.

Monsebraaten, L. (2007, May 10). Woodbine Live deal galvanizes community. The Star. Retrieved from www.thestar.com.

Rexdale Community Hub. (2012). rexdalehub.org.

Shephard, T. (2013, February 6). Woodbine Live! project folds. Etobicoke Guardian. Retrieved from http://www.insidetoronto.com.

SimplyMap (2016). Map with NHS Data 2011. Retrieved March 25, 2016, from SimplyMap Database.

South Etobicoke Industrial Employers Association. Undated. Retrieved from: http://seiea.ca.

Stantec Consulting Site Economics Ltd. (2013). "Metro Vancouver Industrial Land ReDevelopment \& Intensification - Constraints \& Solutions". Prepared for Metro Vancouver.

Techsdale. (2016). techsdale.ca.

Thomas, P. (1968). Rexdale: a case study in suburban industry (Master's Thesis). Retrieved from the Toronto Public Library.

Toronto Official Plan. (Consolidated, December 2010). Obtained from: http://www1.toronto.ca/static_files/CityPlanning/PDF/chapters1_5_dec2010.pdf.

The University of Wisconsin-Milwaukee. (2005). Curbing Industrial Decline or Thwarting Redevelopment? An Evaluation of Chicago's Clybourn Corridor, Goose Island, and Elston Corridor Planned Manufacturing Districts.

Walker, R and Lewis, R. (2004). Beyond the Crabgrass Frontier: Industry and the Spread of North American Cities, 1850-1950. In R. Lewis (Ed.), Manufacturing Suburbs: Building Work and Home on the Metropolitan Fringe. Philadelphia: Temple University Press. 